\title{
Historical fire ecology and its effect on vegetation dynamics of the Lagunas de Montebello National Park, Chiapas, México
}

\author{
Laura Patricia Ponce-Calderón (1), \\ Dante Arturo Rodríguez-Trejo (2), \\ José Villanueva-Díaz ${ }^{(3)}$, \\ Bibiana Alejandra Bilbao ${ }^{(4)}$, \\ Guadalupe del Carmen Álvarez- \\ Gordillo $^{(1)}$, \\ Gabriela Vera-Cortés ${ }^{(1)}$
}

Historical information on wildfires and dendrochronological studies offer meaningful clues about fire and climate regimes, factors that affect forest structure and dynamics. This study aimed to determine the effect of fire history on vegetation dynamics and successional pathways of areas under different fire management policies in the Lagunas de Montebello National Park (LMNP), Chiapas, México. The selected study sites were El Parque area under fire exclusion policies since 1961; Tziscao-inhabited area under fire prohibition since 1984; and Antelá area with a traditional agricultural fire management history. A Pinus oocarpa ring-width chronology was used as a proxy for climate variability to which wildfire occurrence was mapped and to determine the establishment patterns of this dominant species. Current vegetation composition and structure and fuel loads were determined to characterise the study sites. Large wildfires, like those occurring in 1984 and 1998, were associated with periods of high humidity followed by intense droughts; they were linked to strong El Niño events and severely impacted the LMNP. Vegetation dynamics indicated simplification of mesophyll forest (climax) to pine-oaksweetgum forests, with Pinus dominating the overstorey in all sampling sites. Pine, oak and sweetgum species were the dominant juvenile trees in Antelá, EI Parque and Tziscao, respectively. Late-successional seedlings (i.e., Prunus) were present in Antelá and El Parque, while were absent from Tziscao where several wildfires had occurred. Fuel accumulation in sites within protected areas subject to fire exclusion policies was very high (40-68 t ha-1); in contrast, it was the lowest in rural Antelá $\left(24 \mathrm{t} \mathrm{ha}^{-1}\right)$. Considering vegetation vulnerability to wildfires associated with extreme humid-dry climate events, increased fire hazard due to fuel accumulation, and the socio-ecological impacts of these events, we recommend revising the fire exclusion policies currently implemented in the LMNP and applying an integrated fire management approach that incorporates local socio-ecological conditions.

Keywords: Historical Ecology, Dendrochronology, Fire Ecology, Ecological Succession, Fuel Loads

(1) El Colegio de la Frontera Sur, Departamento de Sociedad y Cultura (México); (2) División de Ciencias Forestales, Universidad Autónoma Chapingo. Estado de México (México); (3) Laboratorio de Dendrocronología, INIFAP CENID-RASPA, Gómez Palacio, Durango (México); (4) Departamento de Estudios Ambientales, Universidad Simón Bolívar, Caracas (Venezuela)

@ Laura Patricia Ponce-Calderón (laponce@ecosur.edu.mx)

Received: Oct 21, 2020 - Accepted: Oct 06, 2021

Citation: Ponce-Calderón LP, Rodríguez-Trejo DA, Villanueva-Díaz J, Bilbao BA, ÁlvarezGordillo GDC, Vera-Cortés G (2021). Historical fire ecology and its effect on vegetation dynamics of the Lagunas de Montebello National Park, Chiapas, México. iForest 14: 548-559. - doi: 10.3832/ifor3682014 [online 2021-12-01]

Communicated by: Davide Ascoli

\section{Introduction}

Throughout the world, fire-exclusion policies, together with global warming, resulted in higher environmental and economic impacts of wildfires and human lives and properties lost to fire (Scott et al. 2014). This is a consequence of ignoring natural fire dynamics and excluding fire from fire-dependent ecosystems which increases fuel loads and changes natural fire regimes. On the other hand, it is important to understand that Indigenous communities have knowledge of and value the role of fire in protecting the diversity of biological and cultural ecosystems (Rodríguez-Trejo 2000, Bilbao et al. 2010). In México, fire management concept mostly favours an integrated approach that includes ecological, silvicultural, social, economic, preventive and suppressive aspects, as well as the technical and cultural uses of fire, to maximise the positive and minimise the negative effects of fire, preserve or restore fire regimes, and reduce wildfires (RodríguezTrejo 2000, Myers 2006, Rego et al. 2010).

A fire regime is a pattern of repeated fires through time, expressed as their frequency, season, type, severity and extension over a particular landscape (Scott et al. 2014). In this study, we consider a base fire regime as a natural fire regime under some human influence but not enough to alter or degrade the ecosystem. Whenever fire is excluded or occurs more frequently due to human activity and/or under conditions different from the natural ones (for example, season), the fire regime is altered and will change the ecosystem (Myers 2006, Nielsen-Pincus et al. 2018). This alteration in fire regimes, specifically the increasing extent and severity of wildfires, is a growing threat to biodiversity worldwide (WWF 2020).

The most severe fire seasons recorded in México were in 1998 (14,445 wildfires affecting 849,632 ha) and 2011 (12,113 wildfires affecting 956,405 ha - CONAFOR 2019). The year 1998 was one of the three strongest El Niño years ever recorded (NOAA 2021).

The Lagunas de Montebello National Park (LMNP) is an important biodiversity asset 
that contributes to greenhouse gas $a b-$ sorption and other environmental functions. It is also important from a socia standpoint given the presence of vulnerable human settlements that depend on forest resources for their survival (RamírezMarcial et al. 2010). The LMNP is dominated by fire-dependent ecosystems, according to the classification of Myers (2006); however, it was one of the protected areas of México severely affected by the 1998 fires, as well as the State of Chiapas. Yet the integrated fire management concept is not fully recognised in the State of Chiapas nor in México; this includes the LMNP, where some communities employ fire in diverse ways while others ban its use, which is one of the causes of the mosaic of vegetation in the region.

This study intends to inform forest management decisions in the LMNP, taking into account the interactions between human populations and the environment. Both elements determine the current cultural fire regimes in the region and should be considered in the development of strategies for integrated fire management in a participative and intercultural approach to address global wildfire problems (Rodríguez-Trejo 2014, Bilbao et al. 2019, 2020).

The objectives of this study were to determine the effect of different fire histories on forest species dynamics and the successional routes of the pine-oak-sweetgum forests of the LMNP. We also considered the impact of different fire management approaches currently applied in the LMNP and its surrounding areas in relation to the risks of catastrophic wildfires under future climate change scenarios that predict ex treme wet years followed by severe dry years, such as those experienced in this area in the last few decades. We addressed the research question: what is the effect of different fire management options on the vegetation of the LMNP? We tested the hypothesis that the different fire management histories of the LMNP have differently affected ecological succession and forest fire hazard.

\section{Materials and methods}

\section{Study area}

The LMNP is located in the central-eastern region of the State of Chiapas, México (from $16^{\circ} 04^{\prime} 40^{\prime \prime}$ to $16^{\circ} 10^{\prime} 20^{\prime \prime} \mathrm{N}$ and $91^{\circ} 37^{\prime}$ $40^{\prime \prime}$ to $91^{\circ} 47^{\prime} 47^{\prime \prime} \mathrm{W}$ ), at an altitudinal range of $1500-1800 \mathrm{~m}$ a.s.l. (Fig. 1). The LMNP was stablished in 1959 to protect the high species richness of the mesophyll mountain forests. Some of the causes of the most severe disturbances to these ecosystems and the region's pine-oak forests are the extensive conversion to coffee plantations and pastureland for cattle ranching, illegal and unmanaged logging, and illicit extraction of local flora and fauna. Frequent and large wildfires began to affect the area due to this fragmentation of the landscape and to climate change, which is associated with more extensive and severe droughts (Ramírez-Marcial et al. 2010). Currently, the park's area $(6,425 \mathrm{ha})$ is under the administration of the National Commission of Natural Protected Areas (CONANP 2007).

A temperate sub-humid climate prevails in the region, with an annual mean temperature of $12-18{ }^{\circ} \mathrm{C}$ (García 1998). The annual total precipitation reaches $1862 \mathrm{~mm}$, distributed in two defined periods, one of high humidity from May to December (1716 $\mathrm{mm}$ ) and the other of relative dryness (146 $\mathrm{mm}$ ) from January to April (INEGI 1984). The following ecosystems are found in this region: (i) the mesophyll forest considered to be the climax vegetation; (ii) pine-oaksweetgum forest with several species of $\mathrm{Pi}$ -

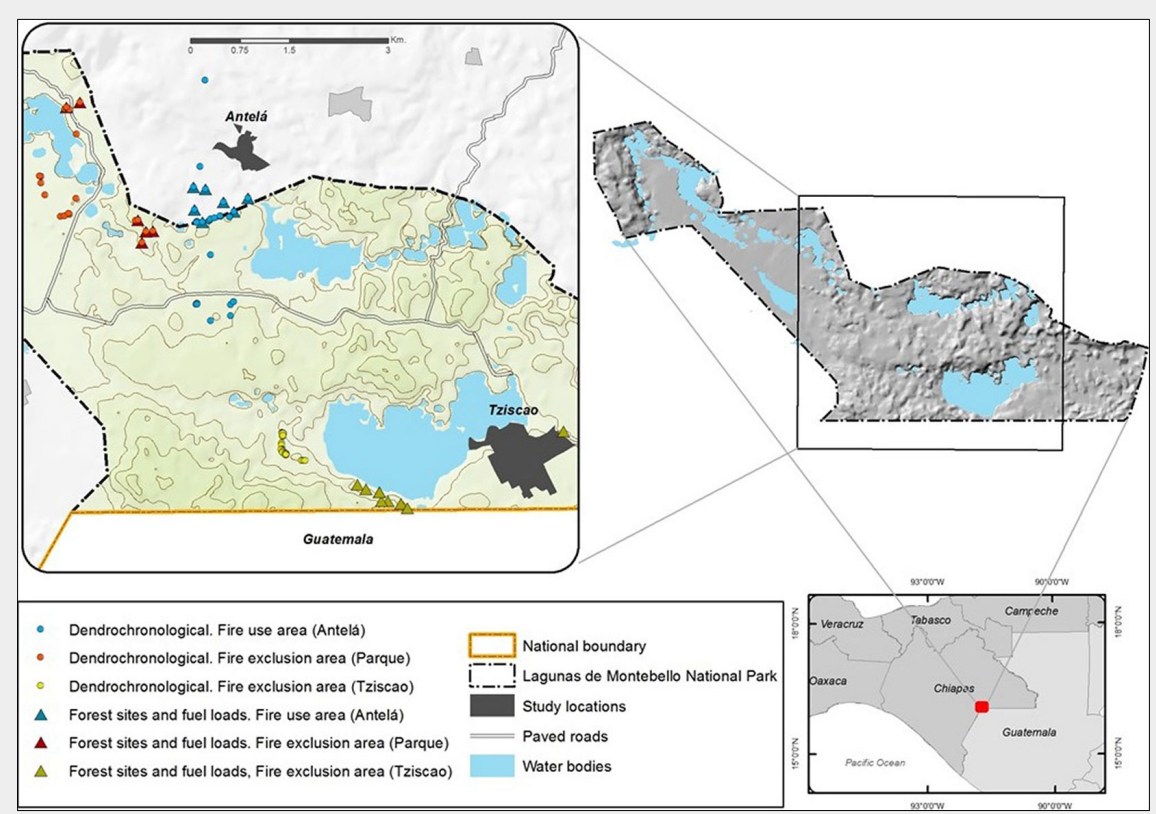

Fig. 1 - Location of the study area, sampling areas and forest sites. nus and Quercus and Liquidambar styraciflua L.; (iii) pine forest dominated by Pinus oocarpa Schiede; and (iv) grassland (Ramírez-Marcial et al. 2010).

Three areas with pine-oak-sweetgum forest as the dominant vegetation, but with different histories of fire management, were included in this study: (1) a fire-use area in Antelá (FUAA - Fig. 1), an Indigenous settlement of Tojolabal origins, located adjacent to the park, where traditional fire management for agricultural purposes is still practised (Ponce-Calderón et al. 2020); (2) a fire-exclusion area located in the core conservation zone of the LMNP (FEAP) where no human settlements are currently found (Fig. 1); fire has been excluded from this zone for more than 50 years (personal communication, CONANP technician 2017); and (3) another fire exclusion area, located in the Ocotal in Tziscao (FEAT - Fig. 1), inhabited by an Indigenous Chuj community of Guatemalan origin, the only human settlement currently found within the LMNP; fire use and wood extraction have been banned since 1998 after a massive wildfire in the area (Ponce-Calderón et al. 2020).

In the different areas characterised by distinct fire management histories, we employed a synchronic approach to study ecological succession through the assessment of plant composition and ecological processes such as natural regeneration of trees, abundance of tree species, annual radial increment and forest fuel load.

\section{Sampling design and sample collection and processing}

\section{Dendrochronological studies}

We selectively sampled $P$. oocarpa specimens to develop a representative tree-ringwidth chronology to extend the series back in time and to maximise the climate signal of the area. We sampled 102 trees, of which 43 were in the FUAA site, 33 in FEAP, and 26 in FEAT. For age structure analysis, in crement cores were extracted at breast height from trees in the dominant diameter classes, giving a total of 187 increment cores. We also collected 10 cross sections of dead individuals or stumps obtained from across the study area (Villanueva-Díaz et al. 2004).

\section{Pinus oocarpa age-size structure}

In order to explore the pattern of recruitment and mortality of $P$. oocarpa and its relation to climate variability and wildfire events, the population age structure of the species was determined by sampling individual trees of different diameter at breast height (DBH) in the study sites.

We defined seven $\mathrm{DBH}$ categories: $\mathrm{A}=$ $10.1-19.9 \mathrm{~cm} ; \mathrm{B}=20.0-29.9 \mathrm{~cm} ; \mathrm{C}=30.0-39.9$ $\mathrm{cm} ; \mathrm{D}=40.0-49.9 \mathrm{~cm} ; \mathrm{E}=50.0-59.9 \mathrm{~cm} ; \mathrm{F}=$ $60.0-69.9 \mathrm{~cm}$; and $\mathrm{G} \geq 70 \mathrm{~cm}$. Two individuals per DBH class were sampled, up to a total of 14 sampled trees per site. Increment cores were extracted at breast height to 
determine the age of each individual tree. The closest approximation of the age of the tree was obtained by adding the num ber of years determined from the increment core, estimate of additional years based on the expected number of tree rings at breast height, and an adjustment for missing years when the pit could not be obtained (Applequist 1958).

\section{Vegetation analyses}

The vegetation in the fire-treatment areas was sampled to determine the effect of different fire histories on vegetation structure, species composition and abundance and the ecological successional dynamics of the forests. Plant specimens were collected in the field and identified later in the herbarium of El Colegio de la Frontera Sur, San Cristóbal de Las Casas, Chiapas.

Tree sampling took place in 24 randomly selected homogeneous (for a particular site) forest stands (eight plots or forest stands per study site), each plot covering a circular area of $1000 \mathrm{~m}^{2}$. Only trees with a $\mathrm{DBH} \geq 12.5 \mathrm{~cm}$ were sampled. The variables considered for each sampled tree were: (i) diameter $(\mathrm{cm})$ of the base of the stem, measured with a diameter tape; (ii) $\mathrm{DBH}$ $(\mathrm{cm})$, measured with a diameter tape; (iii) two cross-crown diameters (m), measured with a metric tape; (iv) cover (\%), estimated from crown diameters; and (v) identification of the species and their status as alive or dead. To sample individuals with a $\mathrm{DBH} \leq$ $12.5 \mathrm{~cm}$, an additional $100-\mathrm{m}^{2}$ concentric plot was demarcated within each 1000-m plot. The number of circular plots of each dimension was 24 (eight per study zone), giving a total of 48 .

To describe the vegetation structure, the following parameters were computed: absolute tree density; mean crown cover; mean basal area; diameter (DBH) distribution; and the importance value index (IVI). The last parameter is an estimator of the ecological relevance of the tree species occurring in a community, computed by summing the relative frequency, relative dominance and relative density of each species.

\section{Fuel load sampling}

Fuel load is considered a valuable indicator of fire history. Frequent fires consume forest fuels while fire exclusion promotes their accumulation. Likewise, high fuel accumulation promotes high fire spread and intensity (Bilbao et al. 2010, Rodríguez-Trejo 2014). In this study, different fuel-load categories were characterised to determine the impact of the fire history of the three treatment areas.

Twenty-four sampling sites, eight per each study site (FUAA, FEAP and FEAT), were selected to determine forest fuel loads; this process involved estimating each type of fuel material, according to the following components. (i) Leaf-litter and fermentation layer components: the cover (\%) of this component within a $0.3 \times 0.3 \mathrm{~m}$ quadrat was visually estimated. Leaf-litter and fermentation layer depths $(\mathrm{cm})$ were also measured with a flexometer. (ii) Herbaceous component (grasses and forbs): a $1.0 \times 1.0 \mathrm{~m}$ quadrat was used to visually estimate the cover of this component, while plant height was measured with a flexometer. (iii) Shrubby component: this component was estimated with a $1.0 \times 1.0 \mathrm{~m}$ quadrat, while plant height and the length and width of crown cover were measured with a flexometer. (iv) Renewal (saplings and resprouts): the cover (\%) of these components was visually estimated, while the heights $(\mathrm{cm})$ of saplings and sprouts within $1.0 \times 1.0$ quadrats were measured with a flexometer. (v) Woody material: we used the line intersect method (Van Wagner 1968) for forest fuel sampling, considering the number of intersections per sampling transect, and with the aid of calipers, measured the diameter of the material at the point the line transect crosses its central axis. We placed three convergent transects, centred on each sampling site, of 3.5 $\mathrm{m}$ in length for woody material in the timelag (TL) classes of 1 and $10 \mathrm{~h}(<0.6$ and 0.6 $2.5 \mathrm{~cm}$ in diameter, respectively), and of 7.0 $\mathrm{m}$ in length for woody material in the TL classes of 100 and $1000 \mathrm{~h}(2.6-7.5 \mathrm{~cm}$ and $>7.5 \mathrm{~cm}$ in diameter, respectively), separating the last classes into "firm" or "rotten".

In addition, we collected and processed 216 samples of every type of fuel from the measured plots. Samples were oven-dried at $80^{\circ} \mathrm{C}$ at the Chemistry Laboratory of the Instituto Tecnológico de Comitán, Chiapas. We also obtained 20 samples of woody material in every TL class (a total of 100 samples) to determine their specific gravity.

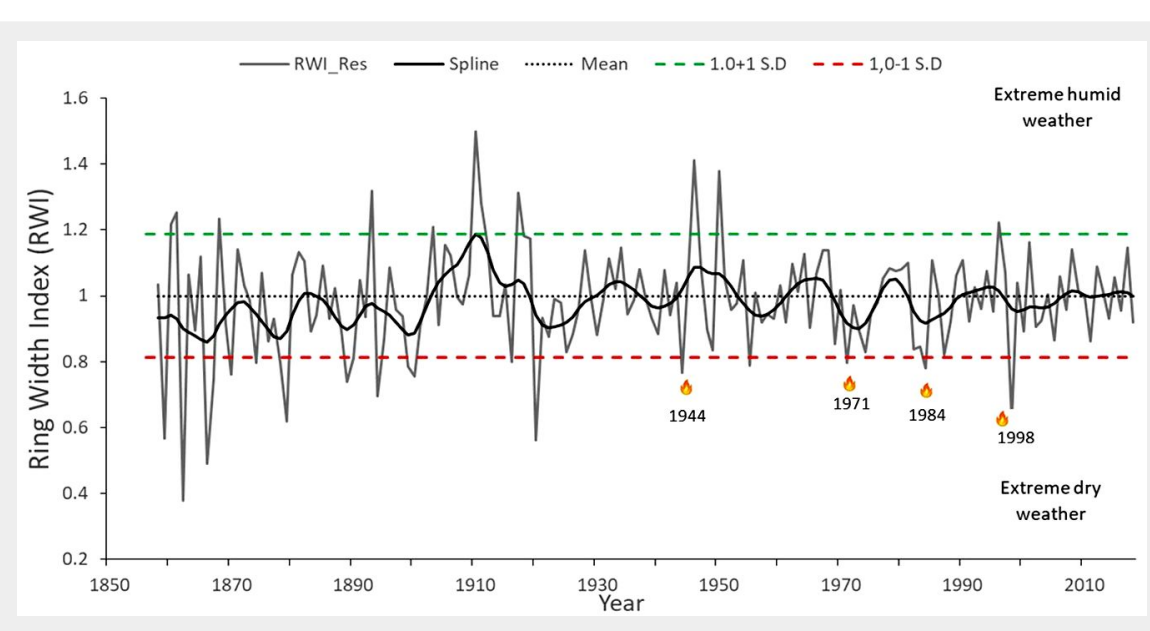

Fig. 2 - Ring-width chronology (residual version) of Pinus oocarpa representative of the dominant climatic conditions in the Lagunas de Montebello National Park. The chronology integrated ring-width series from all sampled sites in the study area. The ring-width index (RWI) of all sampled individuals were smoothed by a flexible decadal line (spline). The dotted horizontal line represents the chronology mean (1.0). The grey vertical curves represent annual values of the dendrochronological series, while the black flexible line is a decadal spline fit to the series to highlight the occurrence of low-frequency events ( $>5$ years). Dashed horizontal green and red lines indicate values one standard deviation above or below the mean, respectively; extreme climatic events occurred out of this range. The flame symbols represent wildfires that occurred during extreme dry weather conditions, i.e., in 1984 and 1998. 
Fig. 3 - Mean annual accumulated growth increase of tree rings from $P$. oocarpa individuals in each study site in the Lagunas de Montebello National Park.

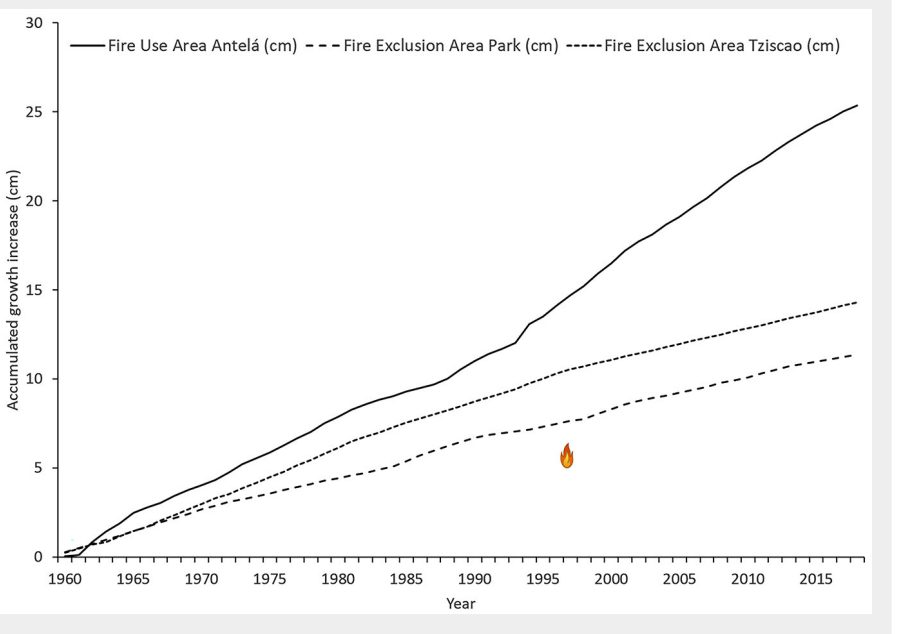

with autocorrelation (red noise) removed was used as a proxy or indirect method to assess the interannual and multiannual variability of the climate of the LMNP. The length of the chronology, with a statistically confident sampling size for climate reconstruction, was based on the expressed population signal (EPS) that must be equal to or greater than 0.85 (Wigley et al. 1984). A t-test was performed to determine whether there were significant differences in the cumulative growth between sampling sites.

ANOVA was performed to test for significant differences in the vegetation structure among fire-history treatment areas. The relationship between age and DBH and its significance were determined by regres-
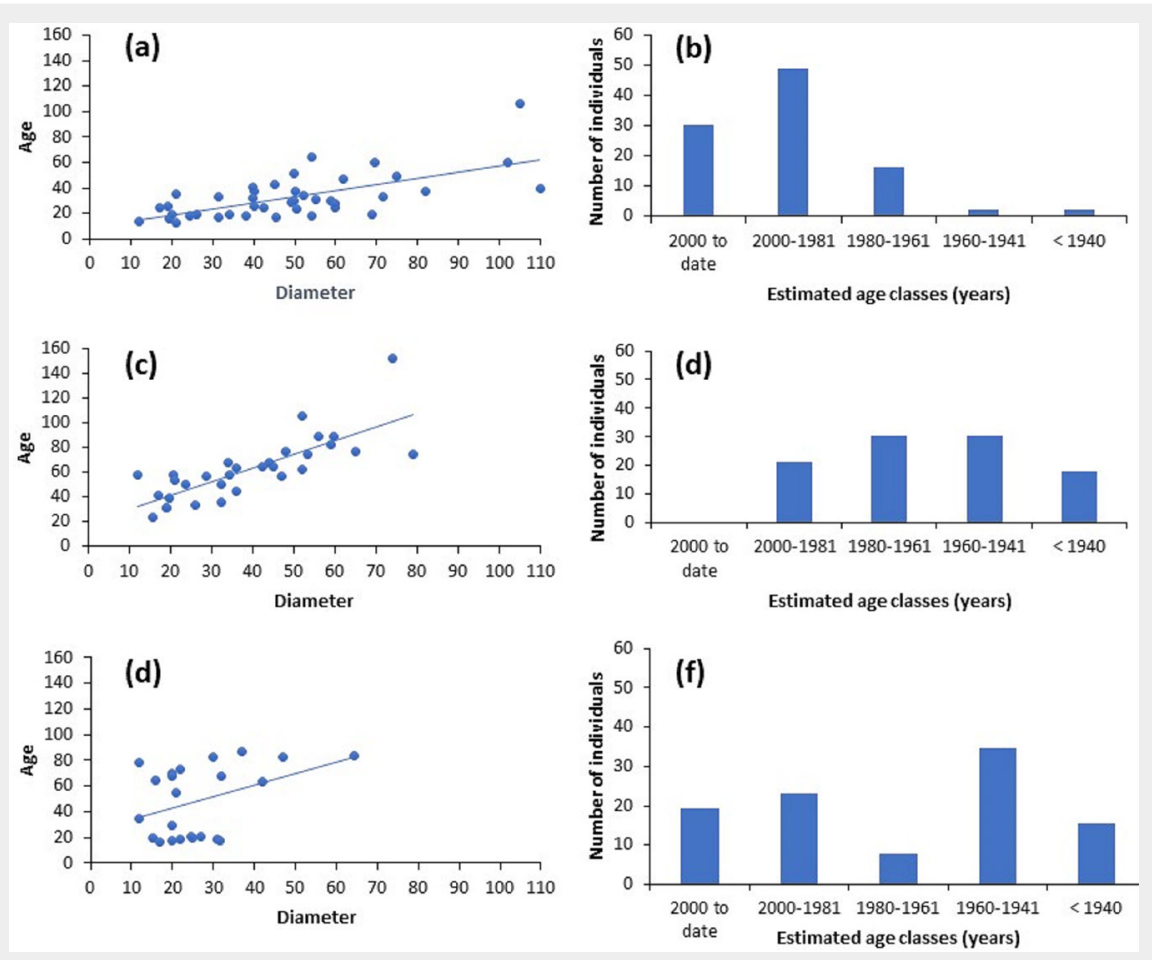

Fig. 4 - (a), (c) and (e): The relationship between diameter at breast height (cm) and age (years) of $P$. oocarpa populations in FUAA, FEAP and FEAT, respectively; (b), (d) and $(f)$ : frequency histograms of the number of trees per age class (years) for $P$. oocarpa populations in FUAA, FEAP and FEAT, respectively. cores. The inter-series correlation was 0.396 , which was significantly higher than the minimum correlation of $0.328(p<0.01)$ required by the COFECHA programme to consider the series properly dated (Holmes 1983).

Given the proximity of the different study sites $(<2.0 \mathrm{~km})$ and the similarity of the prevailing environmental conditions in the region, the ring-width series of the three sites were integrated into a single dataset to obtain a representative ring-width chronology for the LMNP. The ring-width series spanned the years 1856 to 2018 (163 years) and had an EPS of $>0.865$ (Fig. 2).

Based on the annual index values of the chronology and the standard deviation of the mean (Fig. 2), wetter climatic events occurred in 1861, 1868, 1893, 1919, 19461947, 1950, and 1996, while extremely dry years occurred in 1859, 1862, 1866, 1870, 1874, 1879, 1889, 1894, 1899-1900, 1916, $1944,1955,1971,1984$, and 1998. The LMNP's local authorities reported the occurrence of large wildfires in 1984 and 1998 (Fig. 2).

\section{Growth series of $P$. oocarpa}

Dendrochronological information (from 1998 , when the last large wildfire occurred, to 2018) allowed the estimation of the accumulated radial increase of $P$. oocarpa rings in the three study sites (Fig. 3). The differences in the accumulated growth of $P$. oocarpa trees between FUAA $(10.14 \mathrm{~cm})$ and FEAT $(3.60 \mathrm{~cm})$ sites, and between FUAA and FEAP $(3.58 \mathrm{~cm})$ sites were statistically significant $(p<0.01)$. In contrast, accumulated growth was not significantly different ( $p>0.05)$ between FEAT and FEAP.

\section{Age structure and recruitment rates of $P$. oocarpa populations and fire history of the LMNP}

Statistically significant relationships $(p<$ 0.05 ) were found between the DBH of $P$. oocarpa trees and their estimated age for the three study sites (Fig. 4a, Fig. 4C and Fig. 4e). These results indicate that the increase in diameter was associated with the number of tree rings in each diameter class in each of the three study sites. In addition, our analyses allowed to infer recruitment pulses of new $P$. oocarpa individuals through the DBH-age relationship and the frequency histogram of individuals by age class (Fig. 4b, Fig. 4d and Fig. 4f).

A regression coefficient of $R^{2}=0.65$ was obtained for the relationship between diameter and age, with the former explaining $65 \%$ of the variation in the latter, for the $P$. oocarpa population in FUAA. In addition, the frequency histogram of $P$. oocarpa age classes showed that $30.2 \%$ of the trees in FUAA were established within a period of 1 to 6 years after the 1998 wildfire $(<20 \mathrm{~cm}-$ Fig. 4b). Likewise, $19 \%$ of the trees in this site were established after the 1984 wildfire (Fig. 4b).

The linear regression equation for FEAP indicates that $\mathrm{DBH}$ explained $60 \%$ of the 
Tab. 1 - Abundance and importance value index (IVI) for trees and understorey species in the LMNP forests. (D $\mathrm{D}_{\text {abs }}$ ): absolute density; $\left(D_{\text {rel }}\right)$ : relative density; (Freq): frequency; (Freq rel $)$ relative frequency; (DOM): dominance; $\left(D O M_{\text {rel }}\right)$ relative dominance; (IV): importance value.

\begin{tabular}{|c|c|c|c|c|c|c|c|c|c|c|}
\hline Layer & Site & Species & $\begin{array}{c}D_{\text {abs }} \\
\left(\mathrm{n} \mathrm{ha}^{-1}\right)\end{array}$ & $\begin{array}{l}D_{\text {rel }} \\
(\%)\end{array}$ & Freq & $\begin{array}{c}\text { Freq } \\
\text { (\%) }\end{array}$ & $\begin{array}{c}\text { Dom } \\
\left(\mathrm{m}^{2} \mathrm{ha}^{-1}\right)\end{array}$ & $\begin{array}{c}\text { Dom }_{\text {rel }} \\
\text { (\%) }\end{array}$ & IV & $\begin{array}{l}\text { IVI } \\
\text { (\%) }\end{array}$ \\
\hline \multirow{16}{*}{ 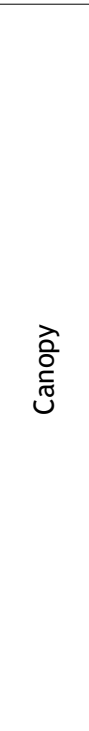 } & \multirow[t]{6}{*}{ FUAA } & Pinus spp. & 120.0 & 36.9 & 1.0 & 29.6 & 2939.4 & 48.3 & 114.8 & 38.3 \\
\hline & & Quercus spp. & 130.0 & 40.0 & 1.0 & 29.6 & 2265.8 & 37.2 & 106.8 & 35.6 \\
\hline & & Liquidambar styraciflua & 68.8 & 21.2 & 0.8 & 22.2 & 838.8 & 13.8 & 57.2 & 19.1 \\
\hline & & Morella cerifera & 2.5 & 0.8 & 0.3 & 7.4 & 15.8 & 0.3 & 8.4 & 2.8 \\
\hline & & Clethra suaveolens & 3.8 & 1.2 & 0.4 & 11.1 & 31.8 & 0.5 & 12.8 & 4.3 \\
\hline & & Total & 325.0 & 100.0 & 3.4 & 100.0 & 6091.4 & 100.0 & 300.0 & 100.0 \\
\hline & \multirow[t]{5}{*}{ FEAP } & Pinus spp. & 175.0 & 63.9 & 1.0 & 32.0 & 7845.5 & 75.4 & 171.3 & 57.1 \\
\hline & & Quercus spp. & 53.8 & 19.6 & 1.0 & 32.0 & 1304.4 & 12.5 & 64.2 & 21.4 \\
\hline & & Liquidambar styraciflua & 41.3 & 15.1 & 0.9 & 28.0 & 1167.5 & 11.2 & 54.3 & 18.1 \\
\hline & & Prunus spp. & 3.8 & 1.4 & 0.3 & 8.0 & 89.8 & 0.9 & 10.2 & 3.4 \\
\hline & & Total & 273.8 & 100.0 & 3.1 & 100.0 & 10407.1 & 100.0 & 300.0 & 100.0 \\
\hline & \multirow[t]{5}{*}{ FEAT } & Pinus spp. & 116.3 & 71.0 & 1.0 & 50.0 & 3351.1 & 72.8 & 193.8 & 64.6 \\
\hline & & Quercus spp. & 23.8 & 14.5 & 0.6 & 31.3 & 539.4 & 11.7 & 57.5 & 19.2 \\
\hline & & Liquidambar styraciflua & 11.3 & 6.9 & 0.3 & 12.5 & 250.0 & 5.4 & 24.8 & 8.3 \\
\hline & & Prunus spp. & 12.5 & 7.6 & 0.1 & 6.3 & 465.3 & 10.1 & 24.0 & 8.0 \\
\hline & & Total & 163.8 & 100.0 & 2.0 & 100.0 & 4605.8 & 100.0 & 300.0 & 100.0 \\
\hline \multirow{18}{*}{ 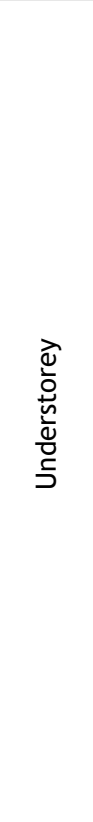 } & \multirow[t]{6}{*}{ FUAA } & Pinus spp. & 312.5 & 62.5 & 0.9 & 41.2 & 536.3 & 45.3 & 149.0 & 49.7 \\
\hline & & Quercus spp. & 37.5 & 7.5 & 0.3 & 11.8 & 65.0 & 5.5 & 24.8 & 8.3 \\
\hline & & Liquidambar styraciflua & 75.0 & 15.0 & 0.4 & 17.6 & 230.0 & 19.4 & 52.1 & 17.4 \\
\hline & & Clethra suaveolens & 37.5 & 7.5 & 0.3 & 11.8 & 83.8 & 7.1 & 26.3 & 8.8 \\
\hline & & Prunus spp. & 37.5 & 7.5 & 0.4 & 17.6 & 268.8 & 22.7 & 47.9 & 16.0 \\
\hline & & Total & 500.0 & 100.0 & 2.1 & 100.0 & 1183.8 & 100.0 & 300.0 & 100.0 \\
\hline & \multirow[t]{5}{*}{ FEAP } & Pinus spp. & 50.0 & 12.5 & 0.3 & 20.0 & 68.8 & 4.8 & 37.3 & 12.4 \\
\hline & & Quercus spp. & 250.0 & 62.5 & 0.5 & 40.0 & 336.3 & 23.5 & 126.0 & 42.0 \\
\hline & & Liquidambar styraciflua & 75.0 & 18.8 & 0.4 & 30.0 & 682.5 & 47.7 & 96.5 & 32.2 \\
\hline & & Prunus spp. & 25.0 & 6.3 & 0.1 & 10.0 & 342.5 & 24.0 & 40.2 & 13.4 \\
\hline & & Total & 400.0 & 100.0 & 1.3 & 100.0 & 1430.0 & 100.0 & 300.0 & 100.0 \\
\hline & \multirow[t]{7}{*}{ FEAT } & Pinus spp. & 25.0 & 6.5 & 0.1 & 5.6 & 50.0 & 3.2 & 15.2 & 5.1 \\
\hline & & Quercus spp. & 100.0 & 25.8 & 0.8 & 33.3 & 246.3 & 15.9 & 75.1 & 25.0 \\
\hline & & Liquidambar styraciflua & 212.5 & 54.8 & 0.9 & 38.9 & 988.8 & 64.0 & 157.7 & 52.6 \\
\hline & & Morella cerifera & 12.5 & 3.2 & 0.1 & 5.6 & 77.5 & 5.0 & 13.8 & 4.6 \\
\hline & & Clethra suaveolens & 25.0 & 6.5 & 0.1 & 5.6 & 86.3 & 5.6 & 17.6 & 5.9 \\
\hline & & Ilex vomitoria & 12.5 & 3.2 & 0.3 & 11.1 & 96.3 & 6.2 & 20.6 & 6.9 \\
\hline & & Total & 387.5 & 100.0 & 2.3 & 100.0 & 1545.0 & 100.0 & 300.0 & 100.0 \\
\hline
\end{tabular}

variation in age of $P$. oocarpa individuals in this zone (Fig. 4C). However, unlike the previous case, the histogram of age classes of P. oocarpa in FEAP (Fig. 4d) reveals a large proportion ( $89 \%)$ of mature pines (30 $\leq \mathrm{x} \leq 81$ years old). It is possible that the fire occurring in 1984 was more intense and severe in FEAP than in FUAA since only $15 \%$ of the trees ( 31 to 36 years old) could establish in FEAP after the fire. According to these results, it is likely that by the beginning of the 1950s, another high-severity forest fire had occurred, given that only $18 \%$ of the individuals ( 62 to 65 years old) were established in that period (Fig. 4d).

The relationship between age and DBH of the 26 sampled $P$. oocarpa trees in the FEAT site had a regression coefficient of $R^{2}=0.40$
(Fig. 4e). The frequency histogram reveals several tree recruitment pulses in this zone, such that $35 \%$ of the trees were likely established after the 1998 forest fire (16- to 21 -year-old trees), while $19 \%$ of the trees may have established after the forest fire occurring in the 1950s (63- to 68-year-old trees - Fig. 4f).

\section{Woody species composition and} abundance in the LMNP

From the entire sampling, a total of 763 individuals were obtained in the $1000-\mathrm{m}^{2}$ sampling units and 1288 in the $100-\mathrm{m}^{2}$ subsampling units distributed in the $\mathrm{DBH}$ classes of $>12.5 \mathrm{~cm}$ and $<12.5 \mathrm{~cm}$ as follows: (i) in FUAA, 325 and 500, respectively; (ii) in FEAP, 274 and 400, respectively; and (iii) in FEAT, 164 and 388, respectively. The total tree species richness of the study area was 15: Pinus oocarpa, P. maximinoi H.E. Moore, Liquidambar styraciflua L., Quercus crispipilis Trel., Quercus elliptica Née, Quercus sapotifolia Liebm., Arbutus xalapensis Kunth, Morella cerifera (L.) Small, Clethra suaveolens Turcz., Ilex vomitoria Aiton, Turpinia tricornuta Lundell, Saurauia scabrida Hemsl., Saurauia villosa DC, Prunus spp., and Podocarpus spp.

Pinus spp., Quercus spp. and L. styraciflua were, together, the species with the highest IVI in the three sampled sites. Pinus spp., followed by Quercus spp. (Magnoliophyta, Fagaceae), were the dominant trees in all sites (Tab. 1). In the understorey, the most abundant were Pinus spp. in FUAA 
Tab. 2 - Mean diameter and standard deviation (SD) of dominant species for each site.

\begin{tabular}{llccc}
\hline $\begin{array}{l}\text { Dominant } \\
\text { Species }\end{array}$ & Parameter & \multicolumn{3}{c}{ Site } \\
\cline { 2 - 5 } Pines & Number of sampled trees $(\mathrm{n})$ & FUAA & FEAP & FEAT \\
\cline { 2 - 5 } & Diameter at breast height $(\mathrm{cm})$ & 45.9 & 140 & 93 \\
\cline { 2 - 5 } & SD $(\mathrm{cm})$ & 15.2 & 16.7 & 22.5 \\
\hline \multirow{3}{*}{ Oaks } & Number of sampled trees $(\mathrm{n})$ & 104 & 43 & 10.8 \\
\cline { 2 - 5 } & Diameter at breast height $(\mathrm{cm})$ & 27.7 & 21.6 & 18.1 \\
\cline { 2 - 5 } & SD $(\mathrm{cm})$ & 10.7 & 14.1 & 8.2 \\
\hline \multirow{2}{*}{ Liquidambar } & Number of sampled trees $(\mathrm{n})$ & 55 & 33 & 9 \\
\cline { 2 - 5 } & Diameter at breast height $(\mathrm{cm})$ & 25.2 & 28.5 & 17.9 \\
\cline { 2 - 5 } & SD $(\mathrm{cm})$ & 9.6 & 17.5 & 7 \\
\hline
\end{tabular}

and Quercus spp. in FEAP, while L. styraciflua was the dominant species in FEAT (Tab. 1). The mean DBH of trees in FUAA and FEAP was larger than in FEAT (Tab. 2).

\section{Fuel loads}

The loads of the different fuel types in the three study sites are described in Tab. 3 . FEAT had the highest total fuel load $(68.1 \mathrm{t}$ $\left.h^{-1}\right)$ in the entire study area. The greatest accumulation of woody material was in the $1000 \mathrm{~h}$ TL class ( $\left.31.6 \mathrm{t} \mathrm{ha}^{-1}\right)$, followed by the fermentation layer $\left(18.8 \mathrm{t} \mathrm{ha}^{-1}\right)$. The lowest fuel load was in FUAA (24.4 $\left.\mathrm{t} \mathrm{ha}^{-1}\right)$, representing $43.4 \%$ and $49.3 \%$ of the loads recorded for FEAT and FEAP, respectively; the fermentation layer showed the highest accumulation in this site (10.34 $\mathrm{t} \mathrm{ha}^{-1}-\mathrm{Tab}$. 3). The difference in total fuel load between FUAA and FEAT was statistically significant $(p<0.01)$, but that between FUAA and FEAP was not significant. In FUAA, wood is used as fuelwood, and fire is a cultural practice in areas surrounding the cornfields.

FEAP had a fuel load of $40.6 \mathrm{t} \mathrm{ha}^{-1}$, which was significantly different $(p<0.01)$ from the fuel load in FEAT (Tab. 3). In FEAP, the highest fuel loads in FEAP were recorded for the fermentation layer $\left(10.5 \mathrm{t} \mathrm{ha}^{-1}\right)$ and the $1000 \mathrm{~h}$ TL class $\left(14.83 \mathrm{t} \mathrm{ha}^{-1}\right)$. The relationships between fire frequency, fuel load and vegetation type in each of the study sites are summarised in Tab. 4.

\section{Discussion}

\section{Climate patterns associated with wildfires}

Climate patterns obtained from the dendrochronological analysis of Pinus oocarpa ring widths showed that the occurrence of large wildfires in the LMNP region was associated with a sequence of extreme humid periods followed by periods of extreme drought (Fig. 2). This pattern was evident for wildfires in 1998 that occurred after a previous humid period in 1996-1997, followed by an extreme dry event in 1998 occasioned by a strong El Niño year. The same situation arose in 1971, when a relatively humid period in 1968-1969 was followed by an extreme dry year and in 1944, when the humid years of 1946-1947 were followed by a severe drought in 1949 (Fig. 2). Forest fuel loads increase and become more available during alternating pluvial and drought periods, respectively (Aragão et al. 2018, Fidelis et al. 2018); these events have triggered extensive and intense wildfires in different regions of México and Central and South America (De la Barrera et al. 2018, Fidelis et al. 2018, Bilbao et al. 2020).

Several previous studies on fire frequency in mixed-temperate forests of central and northern México found that humid climatic conditions prevailing 1 to 2 years prior to a dry year favoured fine material production, an important condition for the occurrence of wildfires (Fulé et al. 2005, Cerano-Paredes et al. 2016). Likewise, the years of recorded wildfires in southern México have been associated with previous moderate La Niña events (rainy years) followed by intense El Niño events (dry years). This was particularly evident during 1987, 1998, 2014 and 2017, when record numbers of 10,942 , $14,445,12,113$, and 8,886 wildfires, respectively, were reported (CONAFOR 2018). This pattern reveals the vulnerability of Mexican ecosystems to increasing wildfire risk under the current climate change conditions, particularly in protected areas where fuel management programmes are scarcely applied.

\section{Following the wildfire footprint in the LMNP}

The age frequency analysis performed in this study allowed us to reconstruct $P$. oocarpa recruitment events in the LMNP. The prevailing age structure of plant populations in natural areas is an indicator of the ability of a particular species to respond to environmental disturbances such as wildfires (Decocq et al. 2005). For instance, a study of Pinus oocarpa var. ochoterenae Martínez in Sola de Vega, Oaxaca showed that fire removes needle litter and grasses, allowing seed direct contact with the mineral soil, which favours germination and promotes natural regeneration, whereas adult tree mortality is kept low (5.3\% - Juárez \& Rodríguez-Trejo 2003).

Our study casts light on the effects of fire on natural conservation areas under different management conditions, since we can compare the results for sites with a history of limited fire use by humans (FEAP and FEAT) with those for another site where fire has been used for traditional agricultural purposes for a long period (FUAA). In this respect, wildfires are the major disturbance in FEAP and FEAT, while shifting cultivation (involving the clearing and burning of vegetation) represents additional disturbances to the natural system in FUAA.

The age frequency histogram for $P$. oocarpa trees recovered from FUAA (Fig. 4a, Fig. $4 \mathrm{~b}$ ) shows that the individuals in the

Tab. 3 - Fuel loads ( h ha $^{-1}$ ) in the Lagunas de Montebello National Park. (*): oaks and sweetgum.

\begin{tabular}{|c|c|c|c|c|c|c|c|c|c|c|c|c|c|}
\hline \multirow[b]{2}{*}{ Site } & \multirow[b]{2}{*}{ Species group } & \multicolumn{5}{|c|}{ Woody materials } & \multirow[b]{2}{*}{$\begin{array}{l}\text { Sub- } \\
\text { total }\end{array}$} & \multirow[b]{2}{*}{ Litter } & \multirow{2}{*}{$\begin{array}{l}\text { Fermen- } \\
\text { tation } \\
\text { layer }\end{array}$} & \multirow{2}{*}{ Grasses } & \multirow[b]{2}{*}{ Forbs } & \multirow[b]{2}{*}{ Shrubs } & \multirow[b]{2}{*}{ Total } \\
\hline & & $1 \mathrm{~h}$ & $10 \mathrm{~h}$ & $100 \mathrm{~h}$ & $\begin{array}{c}1000 \mathrm{~h} \\
\text { firm }\end{array}$ & $\begin{array}{l}1000 \mathrm{~h} \\
\text { rotten }\end{array}$ & & & & & & & \\
\hline \multirow{3}{*}{$\underset{丶}{\stackrel{5}{3}}$} & Pine species & 0.14 & 0.41 & 1.08 & 0 & 0.31 & 1.93 & \multirow{3}{*}{6.57} & \multirow{3}{*}{10.34} & \multirow{3}{*}{0.12} & \multirow{3}{*}{1.46} & \multirow{3}{*}{0.82} & \multirow{3}{*}{24.43} \\
\hline & Broadleaved species* & 0.23 & 0.37 & 1.47 & 0 & 1.12 & 3.19 & & & & & & \\
\hline & Sub-total & 0.37 & 0.79 & 2.55 & 0 & 1.43 & 5.13 & & & & & & \\
\hline \multirow{3}{*}{ 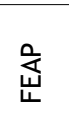 } & Pine species & 0.1 & 0.65 & 1.27 & 9.95 & 2.62 & 14.59 & \multirow{3}{*}{6.92} & \multirow{3}{*}{10.5} & \multirow{3}{*}{0.13} & \multirow{3}{*}{2.88} & \multirow{3}{*}{0.88} & \multirow{3}{*}{40.64} \\
\hline & Broadleaved species* & 0.17 & 0.56 & 1.75 & 0.7 & 1.56 & 4.75 & & & & & & \\
\hline & Sub-total & 0.27 & 1.21 & 3.03 & 10.65 & 4.18 & 19.34 & & & & & & \\
\hline \multirow{3}{*}{ 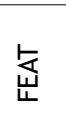 } & Pine species & 0.19 & 0.67 & 2.17 & 22.29 & 6.63 & 31.95 & \multirow{3}{*}{7.38} & \multirow{3}{*}{18.82} & \multirow{3}{*}{0.14} & \multirow{3}{*}{2.38} & \multirow{3}{*}{0.87} & \multirow{3}{*}{68.09} \\
\hline & Broadleaved species* & 0.32 & 0.57 & 3 & 1.1 & 1.56 & 6.54 & & & & & & \\
\hline & Sub-total & 0.51 & 1.24 & 5.18 & 23.39 & 8.19 & 38.49 & & & & & & \\
\hline
\end{tabular}


dominant age class ( $49 \%$ of the total population) established in this site 20 to 40 years ago, while $30.2 \%$ of this population consisted of younger individuals (less than 20 years old).

Considering the above, seed germination requires favourable light and climatic conditions of temperature and humidity, and effective recruitment of new trees takes place a few years after the occurrence of fire (Ramírez-Marcial et al. 2010). The dominant recruitment pattern of $P$. oocarpa in FUAA (Fig. 4b) appears to be associated with the large wildfires that occurred in 1984 and 1998. Effective recruitment of new individuals took place in FUAA in 1985, when humid conditions prevailed in the area as indicated by the larger ring-width indices (RWIs) of P. oocarpa for that year $(\mathrm{RWI}=+1.11)$, as well as for $1999(\mathrm{RWI}=$ +1.04 ) and 2000 (RWI $=+0.89$ - Fig. 2). These humid periods in the LMNP aligned with La Niña events recorded in 1985, 1999, and 2000. These events were followed by 1-2 years of drought, when wildfires were recorded, e.g., in $1984(\mathrm{RWI}=-0.78)$ and 1998 (RWI = -0.62 - Fig. 2), paralleling the occurrence of El Niño events (Golden Gate Weather Services 2020).

Anthropogenic factors also contribute to the environmental and physical conditions of dominant forests (Decocq et al. 2005). The local inhabitants' practice of firewood extraction and use in FUAA promotes the clearing of the forest, letting more incoming light; this also shortens the time of permanence of forest fuels in the zone (Tab. 4), which ameliorates the effect of fires on vegetation. For instance, Pantoja et al. (2018) recorded a $98.9 \%$ survival of $P$. oocarpa individuals in areas treated with low-intensity prescribed burns, compared to much lower survival rates (37.6\%) after severe wildfire in Corazón del Valle, Chiapas.

All these factors seem to contribute to a higher rate of recruitment of new $P$. oocarpa individuals and favour a higher increase in accumulated radial growth $(65 \%$ Fig. 3) in FUAA compared to FEAP and FEAT. A positive effect of fire on the establishment of new $P$. oocarpa var. ochoterenae individuals was also observed in Sola de Vega, Oaxaca, where 38,850 saplings ha $^{-1}$ were recorded two years after a wildfire (Juárez \& Rodríguez-Trejo 2003). Similar effects were observed in Sololá, Guatemala, five months after experimental prescribed burns, where 3100 seedlings ha and 1000 sprouts ha-1 of P. oocarpa were recorded in burned sites vs. 1200 seedlings ha ${ }^{-1}$ in the unburned control plot (Pérez 2006).

Pinus oocarpa age class distribution showed a different pattern in the strictly protected FEAP site. The majority of individuals were in the mature age classes of 41-60 and 61-80 years, representing over $61 \%$ of the population. No individuals under 20 years of age were found in this site, suggesting low regeneration of pines (Fig. 4d).

Tab. 4 - Fire and vegetation status in the LMNP.

\begin{tabular}{llcc}
\hline $\begin{array}{l}\text { Study } \\
\text { site }\end{array}$ & Vegetation & Fuel load & $\begin{array}{c}\text { Fire management } \\
\text { with agricultural } \\
\text { purposes }\end{array}$ \\
\hline FUAA & $\begin{array}{l}\text { Pine-oak-sweetgum forest with a high rate } \\
\text { of pine renewal }\end{array}$ & Low & Yes \\
\hline FEAP & $\begin{array}{l}\text { Pine-oak-sweetgum forest with a high rate } \\
\text { of oak renewal }\end{array}$ & High & No \\
\hline FEAT & $\begin{array}{l}\text { Liquidambar-pine-oak forest with a high } \\
\text { rate of sweetgum renewal }\end{array}$ & Very high & No \\
\hline
\end{tabular}

The long exclusion of fires could explain the low occurrence of young pines in FEAP. It is important to note that $P$. oocarpa is a fire-dependent species that requires frequent low-intensity fires that reduce litter and grasses and allow more light to reach the forest floor, thus enabling tree regeneration (Rodríguez-Trejo 2014). On the other hand, the 1984 wildfires seem to have promoted the recruitment of this species, since $15 \%$ of the population was between 31 and 36 years of age. It is also possible that large wildfires occurred by the end of the 1950 s and the beginning of the 1960 s, as well as in 1948-1949, which would explain the dominance of 41-60-year and 61-80-year age classes (Fig. 4d).

The climatic data obtained for this region from the dendrochronological study indicate humid conditions in 1950 (RWI = +1.38), $1951(\mathrm{RWI}=+1.05)$ and 1955-1956 $(\mathrm{RWI}=+0.90)$, which occurred after extreme dry years when wildfires occurred, for example, in 1948 (RWI = -0.9), 1949 $(\mathrm{RWI}=-0.84)$, and $1951-1952(\mathrm{RWI}=-1)$, respectively (Fig. 2). The abovementioned humid periods matched weak (1950 and 1951) and moderate (1955-1956) La Niña events, while the 1951-1952 drought period matched a moderate El Niño event (Golden Gate Weather Services 2020). According to this, and similar to FUAA's case, $P$. oocarpa recruitment processes in FEAP are associated with periods of high or even extreme humidity under La Niña conditions.

The dominant age class in FEAT was 61-80 years ( $35 \%$ of the $P$. oocarpa population). As in the case of FEAP, this class corresponds to mature individuals probably established after the 1948-1949 wildfires. However, unlike FEAP, young trees $<20$ years were better represented in FEAT (19\%). This could be a consequence of the 1998 wildfire that affected this site. According to CONAFOR data, some wildfires reported in 2010 in this zone could also have contributed to the recent recruitment of pine trees in FEAT.

The 20-40-year age class was also represented in FEAT (23\%), as in the other two sites, indicating that the 1984 wildfires covered the entire study area. The age class with the lowest frequency in FEAT was that of 41-60 years, associated with the 1958 wildfires in the case of FUAA and FEAP. However, the magnitude of these wildfires does not appear to have positively affected the recruitment of young individuals. During interviews, the inhabitants of the FEAT site mentioned an extremely severe wildfire that occurred in the area in 1962 that would correspond to that particular age class. According to the information retrieved from the cross section of one $P$. oocarpa individual from FEAT, this wildfire occurred in 1962.

The results of the dendrochronological study showed that humid periods after 1962 were not very evident nor very prolonged in FEAT; therefore, it is likely that this condition interfered with the effective recruitment of new individuals in this site. In addition, the significant accumulation of forest fuels shown in previous studies suggests that the 1962 wildfire could have reached a very high magnitude. This wildfire occurred only four years after the 1958 wildfire; therefore, a second wildfire event in such a short time could also have eliminated any recently recruited seedlings and saplings.

The link between extreme humid-dry climatic events and wildfires and subsequent $P$. oocarpa regeneration in this study reflects the correlation between climate variability and synchronous reproduction in seed plants in most of the Earth's biomes (Ascoli et al. 2021). For instance, in boreal forests of North America, the onset of El Niño leads to regional drought and heat pulses that facilitate both wildfires and floral bud initiation in Picea glauca. The masting in the following year, as well as the reduction in litter and creation of canopy openings caused by fire, favours $P$. glauca recruitment (Ascoli et al. 2021).

\section{Forest fuel loads}

The fuel loads of a particular ecosystem depend on the patterns of growth, site productivity and type of vegetation, and they can increase under natural and human disturbances, including fire exclusion from an ecosystem (Bilbao et al. 2010, Scott et al. 2014). The fuel loads observed in the three sampled sites were apparently related to the type of fire management in each case. Thus, the FUAA site where fire is still used for agricultural purposes had the lowest values for forest fuel load, which were similar to the values for $P$. oocarpa pine forests of Villaflores, Chiapas (27.3 t ha $^{-1}$ ), where fire is regularly applied for cattle raising and agricultural purposes (Ro- 
dríguez-Trejo et al. 2019a).

As expected, the largest accumulation of forest fuels was observed in the sites subject to fire exclusion $(p<0.05)$. In FEAP, besides fire exclusion, vegetation is sanitised by cutting down trees affected by bark beetles. This may explain, in part, the availability of firm woody fuels observed in this site. In FEAT, in addition to the exclusion of fires, firewood extraction is prohibited in the Ocotal sector. This seems to have contributed to a very high accumulation of forest fuels (68.0 $\mathrm{t} \mathrm{ha}^{-1}$ ) at this site which surpasses the loads recorded for FEAP and is even higher than those previously found in a tropical pine-oak forest with several years of fire exclusion (45.2 $\left.\mathrm{t} \mathrm{ha}^{-1}\right)$, located in a similar region in Villaflores, Chiapas (Rodríguez-Trejo et al. 2019b).

Fuels are one of the three factors, the others being weather and topography, that determine fire behaviour. Thus, when there is accumulation of fuels due to fire exclusion, wildfire incidence, intensity and severity can increase (Myers 2006). These wildfires can transform into large forest fires, especially under extreme weather conditions.

Latin America has experienced events of this type, such as those that occurred in the Cerrado of Brazil in 2015, Chile in 2017 and Bolivia in 2019; the fire regimes in all these places have been altered due to fire exclusion or suppression policies (Fidelis et al. 2018, De la Barrera et al. 2018, Tedim et al. 2018, Bilbao et al. 2020). México is no exception; large fires occurred in the critical seasons of 1998 and 2011, which are documented and also recorded in people's memories. Some studies have demonstrated the negative effects of fire when fuel loads are high or when fires of higher intensity and severity are relatively infrequent. Such is the case reported by $\mathrm{Ca}$ dena-Zamudio et al. (2020) in a study of temperate oak and pine-oak forests in Jalisco, México, which showed that the greater the intensity and severity of the fire, the more the soil's chemical properties $(\mathrm{pH}$ and chemical components) are affected and the diversity of species in the understorey is reduced.

The high fuel loads in the LMNP are not very encouraging for the FEAT and FEAP conservation areas, since they represent a high wildfire hazard, especially considering that extreme drought has been predicted for the region during the 2018-2023 period (IPCC 2012). The only component of the fire triangle that can be manipulated is fuel. The management of fuel loads in the area is one of the potential solutions to prevent catastrophic wildfires, such as those experienced in 1998. A high-severity fire in the LMNP is likely when drought and an ignition factor coincide, as long as planned fire management and cultural uses of fire continue to be excluded, as pointed out by Ponce-Calderón et al. (2020). In this case, the authorities should be prepared to fight major wildfires.

Fire use is not only a tool to prevent large wildfires, but also serves to maintain ecological processes, biodiversity and landscapes (Montiel-Molina \& Kraus 2010). Wynecoop et al. (2019) highlighted the importance of retaining fuel management practices that are part of the local populations' cultural knowledge to promote fire reduction and improve the joint management of ancestral territories influenced by fire. The Cerrado of Brazil and the Canaima National Park of Venezuela are examples of how protection of the ecosystem and fire management by local communities can effectively coexist in order to reduce the threat of large wildfires, especially under the effects of climate change (Bilbao et al. 2009, Fidelis et al. 2018).

Vegetation dynamics associated with wildfire occurrence: three different fire histories in one community

The mesophyll forest in the LMNP is cur- rently reduced to small areas within the park. This ecosystem has a restricted distribution and is not as extensive as the pine and oak forests. While there are indicator species specific to these ecosystems, i.e., Prunus brachybotrya, Synardisia venosa and Styrax magnus (Ramírez-Marcial et al. 2010), the mesophyll forest is characterised by a combination of different functional types ranging from deciduous to evergreen species. Liquidambar styraciflua is a characteristic species of the mesophyll forest at 600-2000 $\mathrm{m}$ a.s.l., although it does not appear to be a dominant species (Rzedowsk 2006). These characteristics of the mesophyll forest, along with high moisture requirements, absence of direct sunlight in its understorey, and structured soils, make it more vulnerable to different types of disturbances, such as wildfires and climate change. The mesophyll forest is concentrated towards the windward sides of the Sierra Madre Oriental (800-1400 m a.s.l.) at the cloud condensation height level (Rzedowski 2006).

There is a rich tradition of natural resource use in Indigenous practice in Mesoamerica and the whole Chiapas region (González-Espinosa et al. 2008, Ponce-Calderón et al. 2020). Fire, in particular, has been an essential management tool used in agriculture, hunting, and fruit gathering by Indigenous communities throughout Latin America (Bilbao et al. 2019).

In this sense, the study of the composition, structure and dynamics of the vegetation of the pine-oak-sweetgum forests under different fire histories in and around the LMNP represents an excellent opportunity to evaluate the impact of fire and the climatic variability of the region on the successional dynamics of these ecosystems.

Based on fire-adaptation characteristics, the following vegetation development stages were found in the LMNP (Fig. 5).

(1) Mountain pastures (herbaceous and grass species): Considered an initial stage

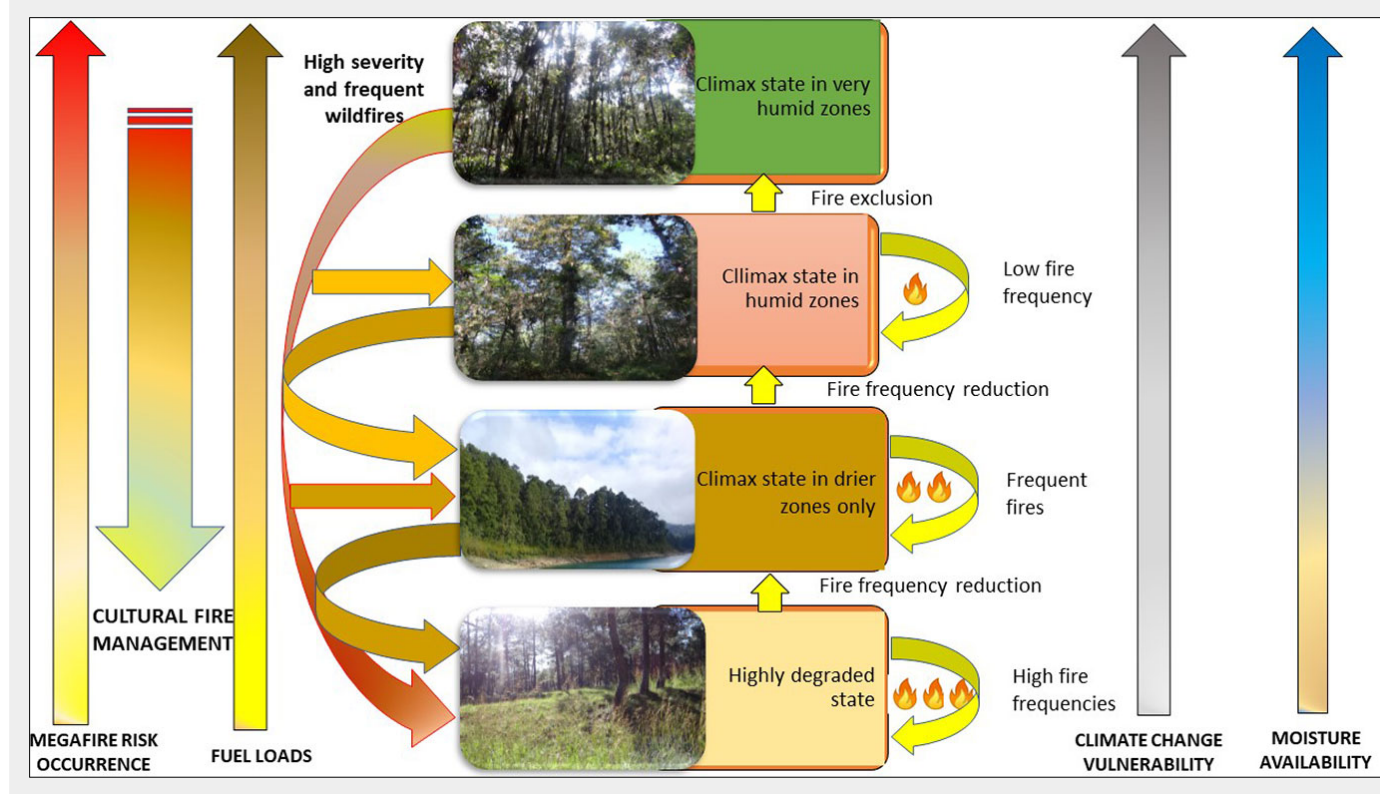

Fig. 5 - Vegetation dynamics in the Lagunas de Montebello National Park under fire occurrence and cultural management practices. From top to bottom: mesophyll forest, pine-oaksweetgum forest, pine forest, and grassland. 
of succession, these are composed of Pteridium sp., Lippia sp., Stipa sp., and Muhlenbergia sp. (CONANP 2007). They are also the result of the degradation of pine, pineoak-sweetgum, or mountain mesophyll forests. Relation to fire: These ecosystems have a relatively low fuel load, and, consequently, they can sustain fires of variable intensity - low intensity if grasses are not very dry and are on flat lands without winds, but high intensity if grasses are very dry and on steep slopes with strong winds. However, fires are necessary for pasture maintenance (for grasses and Pteridium species) since high fire occurrence limits the establishment of tree seedlings. Fire risk: The risk lies in the proximity of these ecosystems to forest ecosystems. Fire spreads easily in grasslands and can reach the edges of forest ecosystems with a high accumulation of combustible material and start large fires.

(2) Pine forest: This forest ecosystem is dominated by $P$. oocarpa representing the early stages of succession. In warmer and drier sites, the ecosystem is a climax community (CONANP 2007). Likewise, several communities dominated by $P$. oocarpa seem to represent successional phases or stages caused by disturbance of the Quercus or Quercus-Pinus forest (Rzedowski 2006). Relation to fire: $P$. oocarpa requires frequent low-intensity fires because it is a fire-dependent species (Rodríguez-Trejo et al. 2019b). Fire risk: Due to its high flammability, pine forest, like pine-oak forest and canopy continuity, poses a high risk of large fires especially under the conditions of alternating highly humid periods (Niña years) and very dry periods (Niño years), as explained above. Adequate fuel management programmes, such as prescribed burns or controlled burns (Indigenous management), are recommended for reducing fuel loads. The use of dead wood can be another way to remove fuel from the area.

(3) Pine-oak-sweetgum forests: These forests are dominated by pines, oaks and sweetgum (Tab. 1). However, our results showed that the species composition and dominance of the understorey differed between study sites. In addition, based on the accumulation of forest fuels, three succesional stages ( $3 a, 3 b$, and $3 c$ ) were identified as described below.

(3a) Pine-oak-sweetgum forests with seedlings/saplings dominated by Pinus spp. ( $50 \%$ of the IVI - Tab. 1). The FUAA site, where traditional agricultural fire management is practised (Ponce-Calderón et al. 2020), corresponds to this vegetation type. Age histograms for $P$. oocarpa showed high regeneration of individuals after the 1998 fire ( $<20$ years), indicating the pioneer character of this species and its high capacity for renewal after fire (Girón 2007). Link to fire: $P$. oocarpa requires frequent low-intensity fires because it is a fire-dependent species (Rodríguez-Trejo et al. 2019a). Although there is evidence of regeneration of Quercus and L. styraciflua, improved light conditions in the understorey as those produced by forest thinning for agricultural activities seem to enhance the growth rates of $P$. oocarpa individuals. Of the three study sites, FUAA corresponds to an earlier successional stage. However, the presence of seedlings/juveniles of Prunus sp. ( $16 \% \mathrm{IVI})$, a species typical of mesophyll and late successional forest (González-Espinosa et al. 2006), indicates that succession is ongoing. Fire risk: Despite the high flammability of Pinus spp. and the continuity of the canopy, adequate fuel management in FUAA could reduce the risk of large fires (its fuel load is $50 \%$ less than that of FEAP and $75 \%$ less than that of FEAT). Although P. oocarpa mortality barely reached $2 \%$ under conditions of low-severity fires, it can reach up to $96 \%$ under high-severity fires in the Villaflores municipality, Chiapas (Rodríguez-Trejo et al. 2019a). Despite the devastating impact of the 1998 fire on the entire region, effective fire management in FUAA by the Indigenous communities seems to have prevented $P$. oocarpa mortality at this study site. The risk of large fires in this zone is associated with its proximity to the LMNP, since the natural park has no fire management or fuel management programme. Under conditions of severe drought (i.e., similar to those in 1998, a strong El Niño year), the LMNP could become a focus of fire propagation to neighbouring areas.

(3b) Pine-oak-sweetgum forests with regeneration dominated by Quercus spp. (Tab. 1). The FEAP site, which has been under fire exclusion measures since LMNP was established in 1959, corresponds to this vegetation type. Seedlings/saplings of Quercus ( $42 \% \mathrm{IVI}$ ) are dominant. Link to fire: The dominance of Quercus and the presence of L. styraciflua and Prunus spp. in the renewal layer indicate that the 60 years of fire exclusion has been effective in promoting ecological succession processes. This study site represents an intermediate stage of succession. Risk of fires: Unlike in FUAA and FEAT, there is no human presence nor use of fire in this area. As discussed above, this situation has led to a significant accumulation of fuel (especially the woody component). As a consequence, and considering the possibility of extreme humidity/drought caused by climate change, this site should be regarded as at high risk of large fires, not only the FEAP site which is under fire exclusion, but also all the surrounding ecosystems inside and outside the LMNP.

(3c) Pine-oak-Sweetgum forests with regeneration dominated by Liquidambar styraciflua (Tab. 1). The FEAT site, which is currently under fire exclusion after the 1998 wildfires, corresponds to this vegetation type. Despite the presence of human settlements in the site, wood extraction activities and other traditional uses of fire are prohibited. The species component of the FEAT understorey was found to be domi- nated by the seedlings/young plants of $L$. styraciflua ( $50 \% \mathrm{IVI})$, followed by Quercus spp. (25\% IVI). The IVI of Pinus was only $5 \%$. Individuals of Prunus spp. were not found in this stratum. Instead, Ilex vomitoria ( $7 \%$ IVI), considered a species of intermediate successional stages, and Morella cerifera ( $5 \% \mathrm{IVI})$ of early successional stages were found (González-Espinosa et al. 2006). Link to fire: The exclusion of fire seems to have promoted the presence of more shade-tolerant seedlings, such as Liquidambar styraciflua and Quercus sp., together with intermediate (e.g., Ilex vomitoria) and early successional species (e.g., Morella cerifera), in this site. This mix of species, as well as the absence of seedlings/saplings typical of mountain mesophyll forests (such as Prunus spp.) found in FUAA and FEAP, suggests that this site is at a successional state intermediate between those of the two previous sites.

Increased forest regeneration needs the occurrence of disturbances such as fire in order to open clearings that provide growing space for seedlings, as well as a synchronised and abundant production of seeds. For successful forest renewal, new fires that eliminate saplings and sprouts should not occur at all. Therefore, the establishment of new shade-tolerant species typical of successional stages subsequent to the pine stage is only possible when fires become less frequent (Rodríguez-Trejo 2014). It is likely that the sequence of wildfire events described for FEAT (see Results) had an impact on mature mesophyll forest species (such as Prunus spp.) which limited their establishment. Risk of fires: Although FEAT is the only human settlement belonging to the Chuj Indigenous people, the LMNP and local authorities have prevented them from collecting firewood and, in general, from performing activities associated with the traditional use of fire. As discussed in the previous section, and similar to what has happened in FEAP, this situation has led to significant accumulation of fuel (especially the woody component) at even a greater extent than that observed in FEAP. Therefore, considering the possible extreme humid/drought events caused by climate change, this site and the surrounding ecosystems inside and outside the LMNP, should be regarded as having the highest risk of large fires.

(4) Mesophyll mountain forests: According to Ramírez-Marcial (2003), the mesophyll mountain forest areas that are exposed to disturbances, such as timber extraction, grazing and fire, show a simplified association of Pinus tecunumanii, Quercus candicans and Liquidambar styraciflua, instead of that of Quercus benthamii, Podocarpus spp. and Magnolia sharpii generally dominating less disturbed forests. Link to fire: Of all the ecosystems of the LMNP, this is the most vulnerable to fire, with limited capacity for post-fire regeneration, especially after large wildfires. This is due to its lack of fire tolerance, and the high mois- 
ture and shade conditions required for regeneration of the species characteristic of mesophyll forest (Rodríguez-Trejo 2014) This ecosystem is regarded as the climax stage under the humid conditions of the highlands of Chiapas (Rzedowski 2006). The catastrophic wildfires of 1998 in Los Chimalapas, Oaxaca, devastated the mountainous mesophyll forest, causing sweetgum trees to lose their shoots, although some resprouted afterwards from the base (Asbjornsen \& Gallardo 2004). However, these plants cannot survive under in creased fire frequency because the trees exhaust their carbohydrate reserves and are unable to resprout again (Coladonato 1992). Risk of fires: Because of its intrinsic wet condition, this forest has the lowest fire risk under normal circumstances. However, under dry conditions this risk increases, and surface and ground fires damage the shallow tree roots causing very high tree mortality. After a fire, woody fuel from the standing dead trees accumulates and the reduction in cover caused by fire increases fuel availability; therefore, a burned mesophyll mountain forest has a higher risk of fire than an unaltered one.

\section{Conclusions}

The ring-width chronology of $P$. oocarpa developed for the LMNP, extending from 1856 to 2018 , constituted a proxy for the dominant climatic conditions of the study area. Extreme climatic events expressed as one standard deviation above or below the mean were characterised by wet conditions one or two years before a wildfire event and dry conditions in the wildfire year.

New forest stands have emerged in sites where severe wildfires have occurred in the past in dry years (El Niño) which followed wet years (La Niña). We propose the following model of vegetation dynamics that considers natural regeneration and population changes in relation to the occurrence of wildfires in the LMNP.

Under the occurrence of wildfires, processes of ecosystem change will proceed through different paths according to these conditions: when fire frequency is very high (i.e., annual) only grasslands or pastures persist, limiting the establishment of pine forests, but when fires are less frequent, a mixed pine-oak forest is observed. Pine forests also occur under dry conditions. When wildfires are infrequent, oak and sweetgum species form an association with pine trees. In wetter sites where fire has been excluded, species characteristic of mountain mesophyll forest occur, such as oak, sweetgum, Podocarpus spp. and Prunus spp.

In this region, the wide knowledge and practices of local communities provide legitimacy for fire use, and should be integrated into fire management plans, as well as linking forest and biodiversity protection and sustainable livelihoods of the population to fire ecology, fire prevention and firefighting objectives. Thus, traditional cultural practices of rural and Indigenous communities, such as firewood extraction, opening and rehabilitation of firebreaks, and local organisation for controlled burning of agricultural land, can reduce the frequency and impact of wildfires, as a direct consequence of decreased fuel loads preventing the spread of fires. Thus, the support and promotion of indigenous fire practices and prescribed burns could provide low-technology, sustainable solutions to deal with the threats of wildfire and represent a valuable strategy of adaptation to climate change scenarios that predict megafires.

\section{List of abbreviations}

The following abbreviations have been used throughout the paper:

- ANOVA: Analysis of variance;

- DBH: Diameter at breast height;

- EPS: Expressed Population Signal;

- INIFAP: Instituto Nacional de Investigaciones Forestales, Agrícolas y Pecuarias;

IVI: Importance Value Index;

- LMNP: Lagunas de Montebello National Park;

- PROC TTEST: TTEST Procedure in SAS ${ }^{\circledR}$;

- PROC NPAR1WAY: SAS/STAT ${ }^{\oplus}$ NPAR1WAY Procedure;

- $\mathrm{R}^{2:} \mathrm{R}$ squared statistical coefficient;

- TL: Time lag:

- RWI: Ring Width Index.

\section{Acknowledgements}

We are grateful to the Antelá and Tziscao communities for allowing us to carry out our study in their areas. The lead author acknowledges CONACYT and ECOSUR for funding this study as part of her Ecological and Sustainable Development doctorate research. The participation of BAB was under the framework of the LANDMARC project "LAND-use based Mitigation for Resilient Climate pathways", the European Union's Horizon2020 research and innovation programme under grant agreement no. 869367.

\section{Author Contributions}

LPPC conceived the study and methodology, took field measurements, curated the samples, processed data, performed statistical analysis and bibliographic investigations, conceptualised the ecological model, and wrote the original draft; DART conceived the study, contributed to data processing and validation, statistical analysis (forest fuels, ecology), bibliographic investigations, methodology, overall supervision, ecological model conceptualisation and review, and the writing, reviewing and editing of the paper; JVD, conceived the study and methodology, took field measurements, curated the data, validated the data processing, carried out statistical analysis (dendrochronology), provided resources, software, supervision, and training, contributed to the writing, reviewing and editing of the paper, and acquired funding for the study; $B A B$ participated in conceptualisation and development of the research paper structure and content, bibliographic investigation, supervision, data processing validation and statistical analysis, ecological model conceptualisation and reviewing, and writing and editing the paper; GCAG, conceived the study, administered the project, provided resources and supervision, wrote, reviewed and edited the paper, and acquired funding; and GVC, conceived the study, provided supervision, and wrote, reviewed and edited the paper.

\section{References}

Applequist MB (1958). A simple pith locator for use with off-center increment cores. Journal of Forestry 56: 141.

Aragão L, Anderson L, Fonseca M, Rosan T, Vedovato L, Wagner F, Silva CVJ, Silva CHL, Arai E, Aguiar A, Barlow J, Berenguer E, Deeter M, Domingues L, Gatti L, Gloor M, Malhi Y, Marengo JA, Miller J, Phillips O, Saatchi S (2018). $21^{\text {st }}$ Century drought- related fires counteract the decline of Amazon deforestation carbon emissions. Nature Communications 9: 536. - doi: 10.1038/s41467-017-02771-y

Asbjornsen H, Gallardo C (2004). Impactos de los incendios de 1998 en el bosque mesófilo de montaña en Los Chimalapas, Oaxaca [Impact of the 1998 wildfires in the mountain mesophyll forest in Los Chimalapas, Oaxaca]. In: "Incendios Forestales en México. Métodos de Evaluación” (Villers RL, López BJ eds) UNAM, México, DF, pp. 125-146 [in Spanish] [online] URL: http://www.atmosfera.unam.mx/wp-content/u ploads/2021/09/Incendios-forestales.pdf\#page= 119

Ascoli D, Hacket-Pain A, Pearse I, Vacchiano G, Corti S, Davini P (2021). Modes of climate variability bridge proximate and evolutionary mechanisms of masting. Philosophical Transactions of the Royal Society B: Biological Sciences 376 (1839): 438. - doi: 10.1098/rstb.2020.0380 Bilbao BA, Leal AV, Méndez CL, Delgado-Cartay $M D$ (2009). The role of fire on vegetation dynamics of upland savannas of the Venezuelan Guayana. In: "Tropical Fire Ecology: Climate Change, Land Use and Ecosystem Dynamics" (Cochrane MA ed). Springer-Praxis, Heidelberg, Germany, pp. 451-480. - doi: 10.1007/978-3-54077381-8_16

Bilbao BA, Leal AV, Méndez CL (2010). Indigenous use of fire and forest loss in Canaima $\mathrm{Na}$ tional Park, Venezuela. Assessment of and tools for alternative strategies of fire management in Pemón Indigenous landscape ecology. Human Ecology 38: 663-673. - doi: 10.1007/s107 45-010-9344-0

Bilbao BA, Mistry J, Millán A, Berardi A (2019). Sharing multiple perspectives on burning: towards a participatory and intercultural fire management policy in Venezuela, Brazil, and Guyana. Fire 2 (3): 39. - doi: 10.3390/fire2030039 Bilbao B, Steil L, Urbieta IR, Anderson L, Pinto C, González MC, Millán A, Falleiro RM, Morici E, Ibarnegaray V, Pérez-Salicrup DR, Pereira JM, Moreno JM (2020). Wildfires. In: “Adaptation to Climate Change Risks in Ibero-American Countries RIOCCADAPT Report" (Moreno JM, Laguna-Defior C, Barros V, Calvo Buendía E, 
Marengo JA, Oswald Spring U eds). McGraw Hill, Madrid, Spain, pp. 435-496. [online] URL: http://www.researchgate.net/publication/3464 87629

Cadena-Zamudio DA, Flores-Garnica JG, FloresRodríguez AG, Lomelí-Zavala ME (2020). Efecto de incendios en la vegetación de sotobosque y propiedades químicas de suelo de bosques templados [Effect of forest fires on the forest understory and soil chemical properties of temperate forests]. Agro productividad 13 (4): 65 72. [in Spanish] - doi: 10.32854/agrop.vi.1684 Cerano-Paredes J, Villanueva-Díaz J, Vázquez-Selem L, Cervantes-Martínez R, Esquivel-Arriaga G, Guerra-De la Cruz V, Fulé PZ (2016). Régimen histórico de incendios y su relación con el clima en un bosque de Pinus hartwegii al norte del es tado de Puebla, México [Historic fire regime and its relationship with climate in a Pinus hart wegii forest in northern Puebla state, Mexico] Bosque 37 (2): 389-399. [in Spanish] - doi: $10.4067 /$ S0717-92002016000200017

Coladonato M (1992). Liquidambar styraciflua. In: "Fire effects information system". USDA Forest Service, Rocky Mountain Research Station, Fire Sciences Laboratory, web site. [online] URL: http://www.fs.fed.us/database/feis/plants/tree/ liqsty/all.html

CONAFOR (2018). Reporte semanal de resultados de incendios forestales [Weekly report of forest fires results]. Comisión Nacional Forestal - CONAFOR, Programa de Manejo del Fuego, Centro Nacional de Manejo del Fuego. Zapopan, Jalisco, México, pp. 18. [in Spanish] [online] URL: http://snigf.cnf.gob.mx/wp-con tent/ uploads/Incendios/2018/Sem\%2050\%2014\%20de $\% 20$ Diciembre.pdf

CONAFOR (2019). Reporte semanal de resultados de incendios forestales [Weekly report of forest fires results]. Comisión Nacional Forestal - CONAFOR, Programa de Manejo del Fuego, Centro Nacional de Manejo del Fuego. Zapopan, Jalisco, México, pp. 18. [in Spanish] [online] URL: http://www.gob.mx/cms/uploads/at tachment/file/522446/Cierre_de_la_Temporada 2019.pdf

CONANP (2007). Programa nacional de Áreas naturales protegidas [National program of protected natural areas]. Comisión Nacional de Áreas Naturales Protegidas (CONANP) 20072012, Mexico DF, web site. [online] URL: http:// www.gob.mx/conanp/documentos/programanacional-de-areas-naturales-protegidas-20202024

Cook ER, Holmes RH (1984). Program ARSTAN and user's manual. Laboratory of Tree-Ring Re search, University of Arizona, Tucson, USA, pp. 15.

Decocq G, Aubert M, Dupont F, Bardat J, Wattez-Franger A, Saguez R, De Foucault B, Alard D, Delelis-Dusollier JA (2005). Silviculturedriven vegetation change in a European temperate deciduous forest. Annals of Forest Science 62: 313-323. - doi: 10.1051/forest:2005026

De la Barrera F, Barraza F, Favier P, Ruiz V, Quense J (2018). Megafires in Chile 2017: monitoring multiscale environmental impacts of burned ecosystems. Science of Total Environment 637 (638): 1526-1536. - doi: 10.1016/j.scito tenv.2018.05.119

Fidelis A, Alvarado ST, Barradas ACS, Pivello VR
(2018). The year 2017: megafires and management in the Cerrado. Fire 1 (3): 49. - doi: 10.339 o/fire1030049

Fulé PZ, Villanueva-Díaz J, Ramos-Gómez M (2005). Fire regime in a conservation reserve, Chihuahua, Mexico. Canadian Journal of Forest Research 35: 320-330. - doi: 10.1139/Xo4-173

García E (1998). Modificaciones al sistema de clasificación climática de Köppen [Modifications to the Köppen climatic classification system]. Instituto de Geografía, Universidad $\mathrm{Na}$ cional Autónoma de México, México, pp. 97. [in Spanish]

Girón E (2007). Monitoreo de efectos ecológicos del fuego y quemas prescritas: vacíos en el manejo forestal y de áreas naturales protegidas en Guatemala, Centroamérica [Monotoring the ecological effects of fire and prescribed burns: vacuums in the forest management and the natural protected areas in Guatemala, Central America]. In: Memorias de "Ecología y Biodiversidad. V Conferencia Internacional Sobre Incendios Forestales". Sevilla (Spain) 13-17 May 2007, pp. 12. [in Spanish] [online] URL: http://www. gfmc.online/sevilla-2007/contributions/doc/cd/s esiones_tematicas/st3/Giron-Solorzano_GUATE MALA_monitoreo.pdf

Golden Gate Weather Services (2020). El Niño and La Niña years and intensities based on Oceanic Niño Index (ONI). S. Francisco, CA, USA, web site. [online] URL: http://ggweath er.com/enso/oni.htm

González-Espinosa M, Ramírez-Marcial N, Galindo JL (2006). Secondary succession in montane pine-oak forests of Chiapas, México. In: “Ecology and Conservation of Neotropical Montane Oak Forests" (Kappelle M ed), Ecological Studies 185, Springer, Heidelberg, Germany, pp. 209-221. - doi: 10.1007/3-540-28909-7_16 González-Espinosa M, Rey BJM, Ramírez-Marcial N (2008). Restauración de bosques en América Latina [Restoration of forests in Latin America]. Fundación Internacional para la Restauración de Ecosistemas (FIRE) and Mundi-Prensa, México, pp. 252. [in Spanish]

Holmes RL (1983). Computer-assisted quality control in tree -ring dating and measurement. Tree-Ring Bulletin 43: 69 -78. [online] URL: https://repository.arizona.edu/bitstream/handl e/10150/261223/trb-43-069-078.pdf

INEGI (1984). Carta de efectos climáticos regionales [Map of regional climatic effects]. Mayo-octubre y noviembre-abril. Las Margaritas, Aguascalientes, Mexico, scale 1:250.000, E15-12-D15-3. [In Spanish]

IPCC (2012). Climate change 2012: impacts, adaptation and vulnerability. Intergovernmental Panel of Climatic Change - IPCC, Cambridge University Press, Cambridge, UK, pp. 1042.

Juárez A, Rodríguez-Trejo DA (2003). Efecto de los incendios forestales en la regeneración natural de Pinus oocarpa var. ochoterenae Martínez [Effect of forest fires in the natural regeneration of Pinus oocarpa var. ochoterenae Martínez]. Revista Chapingo, Serie Ciencias Forestales y del Ambiente 9 (2): 125-130. [in Spanish] [online] URL: http://www.redalyc.org/pdf/629/ 62913142003.pdf

Montiel-Molina C, Kraus D (2010). Best practices of fire use - Prescribed burning and suppression fire programmes in selected case-study regions in Europe. Report no. 24, European Forest Institute Research - EFI, Joensuu, Finland, pp. 182. Myers RL (2006). Living with fire - Maintaining ecosystems and livelihood with the integral fire management. The Nature Conservancy, Global Fire Initiative, Washington, DC, USA, pp. 28. Nielsen-Pincus M, Evers C, Moseley C, HuberStearns H, Bixler RP (2018). Local capacity to engage in federal wildfire suppression efforts: an explanation of variability in local capture of suppression contracts. Forest Science 64 (5): 480-490. - doi: 10.1093/forsci/fxy011

NOAA (2021). Historical El Nino / La Nina episodes (1950-present). National Weather Service - NOAA, National Centers for Environmental Prediction, Maryland, USA, web site. [online] URL: http://origin.cpc.ncep.noaa.gov/products/ analysis monitoring/ensostuff/ONI_v5.php

Pantoja CV, Rodríguez-Trejo DA, Myers RL, Hernández AE, González SMV (2018). Modelación de la probabilidad de mortalidad de Pinus oocarpa en áreas de quema pres-crita o incendiadas en Chiapas [Modeling the probability of mortality of Pinus oocarpa in prescribed burn or wildfire áreas in Chiapas]. Acta Universitaria 28: 1-9. [in Spanish] - doi: 10.15174/au.2018.1607

Pérez C (2006). Experiencias en quemas controladas, quemas prescritas e incendios forestales en finca forestal nacional de San Jerónimo, Baja Verapaz [Experiences in controlled burns, prescribed burns and forest fires in the national forest farm of San Jerónimo, Baja Verapaz]. Curso básico en planificación de quemas prescritas. San Jerónimo, Baja Verapaz, Guatemala, Instituto Nacional de Bosques, Sistema nacional de prevención y control de incendios forestales, Asociación Vivamos Mejor, The Nature Conservancy, pp. 14. [in Spanish]

Ponce-Calderón LP, Alvarez-Gordillo G, VeraCortés G, Rodríguez-Fernández I, RodríguezTrejo DA, Villanueva-Díaz J (2020). The birth of the "sin fuego" people: a case study in Lagunas de Montebello National Park, Chiapas, Mexico. Nova Scientia 12 (2): 1-47. - doi: 10.21640/ns.v12 i25.2414

Ramírez-Marcial N (2003). Survival and growth of tree seedlings in anthropogenically disturbed Mexican montane rain forests. Journal of Vegetation Science 14: 881-890. - doi: 10.1111/ j.1654-1103.2003.tb02221.x

Ramírez-Marcial N, Camacho CA, Ortíz AD (2010). Forest restoration in Lagunas de Montebello National Park, Chiapas, Mexico. Ecological Restoration 28 (3): 354-360. - doi: 10.3368/er.28. 3.354

Rego F, Rigolot E, Fernandes P, Montiel C, Silva JS (2010). Towards integrated fire management. EFI Policy Brief 4, European Forest Institute, Joensuu, Finland, pp. 16. [online] URL: http://hal.inrae.fr/hal-02823739/document

Rodríguez-Trejo DA (2000). Educación e incendios forestales [Education and forest fires]. Mundi Prensa, UACH, México, pp. 201. [in Spanish]

Rodríguez-Trejo DA (2014). Incendios de vegetación: su ecología, manejo e historia [Wildfires: its ecology, manegement and history]. Vol. 1, Ed. Colegio de Postgraduados, Universidad Autónoma Chapingo, Semarnat, México, pp. 887. [in Spanish]

Rodríguez-Trejo DA, Muñoz-Martínez P, Martín- 
ez-Lara PJ (2019a). Efectos del fuego en el arbolado de un bosque tropical de pino y en el de una selva baja caducifolia en Villaflores, Chiapas [Fire effects on the trees of a tropical pine forest and of a dry tropical forest in Villaflores, Chiapas]. Ciencia Florestal 29 (3): 1033-1047. [in Spanish] - doi: 10.5902/1980509833952

Rodríguez-Trejo DA, Martínez-Muñoz P, PulidoLuna JA, Martínez-Lara PJ, Cruz López JD (2019b). Instructivo de quemas prescritas para el manejo integral del fuego en el municipio de Villaflores y la Reserva de la Biosfera La Sepultura, Chiapas, México [Guide of prescribed burns for the integral fire management at the Villaflores municipality and the La Sepultura biosphere reserve, Chiapas, Mexico]. FMCN, USDA Forest Service, US AID, Biomasa AC, UACH, Mpio, Villaflores, Gob. Edo. Chis., ANCF, SEMARNAT, CONANP, CONAFOR, México, pp. 183. [In Spanish]

Rzedowski J (2006). Vegetación de México [Veg- etation of Mexico] ( $1^{\text {st }}$ edn). Comisión Nacional para el Conocimiento y Uso de la Biodiversidad, México DF, pp. 504. [in Spanish]

Scott AC, Bowman DMJS, Bond WJ, Pyne SJ, Alexander ME (2014). Fire on earth. An introduction. Wiley Blackwell, Singapore, pp. 413.

Tedim F, Leone V, Amraoui M, Bouillon C, Coughlan MR, Delogu GM, Fernandes PM, Ferreira C, McCaffrey S, McGee TK, Parente J, Paton D, Pereira MG, Ribeiro LM, Viegas DX, Xanthopoulos G (2018). Defining extreme wildfire events: Difficulties, challenges, and impacts. Fire 1 (1): 9. - doi: 10.3390/fire1010009

Van Wagner CE (1968). The line intersect method in forest fuel sampling. Forest Science 14: 20-26. [online] URL: http://academic.oup.com/ forestscience/article-abstract/14/1/20/4709615 Villanueva-Díaz J, Cerano-Paredes J, Stahle D, Therrell M, Cleaveland M, Sánchez I (2004). Elementos básicos de la dendrocronología y sus aplicaciones en México [Basic elements of den- drochronology and its applications in Mexico]. Folleto técnico no. 2, INIFAP, CENID-RASPA, Gómez Palacio, Durango, Mexico, pp. 37. [in Spanish]

Wigley ML, Brifa KR, Jones PD (1984). On the average value of correlated time series, with ap plications in dendroclimatology and hydrometeorology. American Meteorological Society 23: 201-213. - doi: 10.1175/1520-0450(1984)023<0201: OTAVOC>2.0.CO;2

WWF (2020). Fires, forests and the future: a crisis raging out of control? World Wildlife Fund WWF, Gland, Switzerland, pp. 21. [online] URL: http://wwfeu.awsassets.panda.org/downloads/ wwf_fires_forests_and_the_future_report.pdf Wynecoop MD, Morgan P, Strand EK, Sanchez TF (2019). Getting back to fire sumés: exploring a multi-disciplinary approach to incorporating traditional knowledge into fuels treatments. Fire Ecology 15: 17. - doi: 10.1186/s42408-019-00 30-3 